\title{
16
}

\section{The Role of the United Nations in Promoting the Policy Debate on Child Allowance Issues in 1960s Japan}

\author{
Naho Sugita
}

\section{Introduction}

The child allowance scheme is one of the key pillars of Japan's family policy. In 1961, the same year as the health insurance and public pension schemes for every citizen came into force, discussions for introducing a child allowance scheme started in a committee established in the Central Child Welfare Council (within the Ministry of Health and Welfare). After that, in 1965, the Ministry of Health and Welfare established a preparatory office for the child allowance scheme. Then, in 1969, the Ministry founded the Child Allowance Council. After twists and turns during ten years of discussion, the government passed the bill to introduce the child allowance scheme in 1971.

Some previous studies have dealt with the child allowance bill formation process (Ohshio 1996; Kita 2008; Ono 2014). The committee set

N. Sugita $(\bowtie)$

Osaka City University, Osaka, Japan

e-mail:naho-sugita@kkh.biglobe.ne.jp 
up in 1961 and the council organised in 1969 had long discussions about those topics, in particular about reducing the economic burden of raising children and funding sources for the proposed policy. The law provided an income-tested allowance which covered third and subsequent children until the end of compulsory education.

The formation process of the child allowance scheme in the 1960s and its provisions and limitations as an enacted bill in 1971 was influenced by the new policy idea of "social development". This idea came from the international context as much as the unique historical context in Japan. The international policy idea was not just imported from the United Nations (UN) but was remade during the import process and subsequently used to renew a policy idea that already existed in Japan. As a result, the concept of social development in Japan diverged from the original one in the UN; but, as I show below, the UN idea was instrumental to this process.

In this paper, I discuss the role of the idea of social development in promoting the policy debate on child allowance issues in 1960s Japan. Interestingly, the concept of social development that appeared in the context of development assistance in the UN brought a dramatic change in Japanese policy debates on human resources and social security, including the child allowance issue. Social development as a Japanese concept was combined with an interest to improve "the quality of population", in particular through the state's role in family planning, while the UN's concept encompassed a more general humanism or psychosocial wellbeing without a state shaping family planning decisions.

\section{The Quality of Population Debates}

Before moving on to the subject of social development, I explain the concept of the quality of population, which had long been the key issue in Japanese policy debate since the 1920s.

Regarding policy debates on population, there are quality issues as well as quantity issues. The concept of the quality of population historically meant both genetic quality (inborn characteristics) and non-genetic quality (acquired characteristics). From a historical point of view, increasing 
attention being paid to the quality of population was fundamentally linked to eugenic-euthenic ideas that were popular in the late nineteenth and early twentieth century in Japan as well as internationally.

Going back in the history of eugenic-euthenic thought, Francis Galton coined the term eugenics in 1883, and Herbert Spencer advocated the theory of social evolution. It is well known that Spencer coined the phrase "survival of the fittest", which is also known as Social Darwinism. His evolutionary thought played a prominent role as a philosophy to build a better society from the end of the nineteenth to the beginning of the twentieth century. In response to this trend, euthenics emerged as an opposing theory of population quality. Ellen Henrietta Swallow Richards, known for her book Euthenics: The Science of Controllable Environment (1910), took evolutionary thinking in an environmental direction, insisting that environmental improvement is more important than genetic improvement. A confrontation ensued between proponents of eugenics and those of euthenics. Though conflictual, the two thoughts shared a common ground in the evolutionary idea that "a better society should be built on bettering people's lives". I call the idea the "eugenic-euthenic principle". ${ }^{1}$ The eugenic-euthenic principle highlighted issues surrounding the "quality" of population and had a great impact on policy debates of the time, such as the maternal welfare and child protection movements. These culminated in several pieces of legislation related to the quality of future generations, including the Child Abuse Prevention Act (Jido Gyakutai Boshi Ho; 1933), the Juvenile Reform Act (Syonen Kyogo Ho; 1933), and the National Eugenic Act (Kokumin Yusei Ho; 1940). These became the basis for population policy in post-war Japan.

Today, we consider the term eugenics to be closely associated with Nazism and the Holocaust. We recognise eugenics as immoral because it also led to ideas and practices of forced sterilisation, which was a process for choosing which types of people were allowed to exist and reproduce in a society. Without going into details, selection based on genetic factors

\footnotetext{
${ }^{1}$ An example of a major eugenic-euthenic thinker in pre-war Japan was sociologist Tongo Takebe (1871-1945). He proposed that the term eugenics could be used in both a narrow and a broad sense. Narrowly, he said, "Eugenics" just means a eugenic approach, but, broadly, it indicates a eugenic-euthenic perspective, which was important for practical application. It was Takebe who translated euthenics into Japanese as yukyogaku. For details, see Sugita (2017).
} 
was carried over to the post-war period, for instance in the practice of forced sterilisation of people with disabilities. This unfortunate history is completely criticised today.

On the other hand, a concern for better lives for people or better future generations, which continued to the post-war period, gave rise to discussions on non-genetic factors for bettering lives and society as a whole. A concern for non-genetic factors stimulated the formation of welfare policies for women and children. This is a positive aspect in the history of the eugenic-euthenic principle. Though, from the present viewpoint, it may be better to distinguish euthenic thought from eugenic thought, participants in the debates at the time recognised the two as a unified concept.

\section{The 1960s as the Era of Social Development}

In the 1950s, the UN began to use the concept of social development, in contrast to simply economic development, as reorienting goals to "improving people's lives" not just economic status. An essential meaning of social development is the improvement of the well-being of every individual in a society so that they can reach their full potential, and thus fosters a family's right to family planning decisions as opposed to the eugenic-euthenic ideas where the state dictates family plans.

In January 1961, the UN declared the 1960s as the Decade of Development. President John F. Kennedy of the USA declared the "UN Development Decade" at a speech before the UN General Assembly in New York in 1961. In response, the United Nations Secretary-General at that time, U Thant, worked hard to promote the programme of the UN Development Decade in dealing with the North-South problem. The UN officially decided on an increase in development assistance for developing countries. After that, Japan also made efforts to expand Official Development Assistance in this context.

In 1963, the United Nations Research Institute for Social Development (UNRISD) was established to design strategies for socio-economic development. Thus, the period from 1960 to 1970 brought about considerable changes in development concepts. The UN came to regard balanced 
social and economic development as important in development assistance. Then, overseas assistance to developing countries had been guided by the two pillars of economic and social development. The success of society came to be linked to the well-being of each and every citizen (US President 1964; US Welfare Administration 1966).

Japan's president of the National Institute of Population Problems (affiliated with the Ministry of Health and Welfare), Minoru Tachi (1906-1972), attended the UN population commission in 1959 and immediately took note of the concept of social development. He soon introduced the concept of social development into the policy debate on population problems in Japan. And, it was Hideo Ibe (1921-2002), then Director of the Minister's Secretariat of the Ministry of Health and Welfare, who translated the term social development into Japanese (shakai kaihatsu). Tachi and Ibe made lasting efforts to introduce the theory of social development into social policy in the early 1960s in Japan. Given that their ideas can be traced directly back to the UN, it is easy to conclude that the UN was a key factor in shaping Japanese social policy, for this process was set in motion because the UN designed and promoted the concept of social development to its delegates.

Back in Japan, where the eugenic-euthenic principle had previously dominated the history of social policy discussions, the concept of social development was seen with both praise and critique. The concept of social development strongly encouraged people to remake eugeniceuthenic thought in the direction of eliminating barriers that limit opportunities for people's full participation in society. However, as the eugenic-euthenic perspective was so strong in Japan, the ideas from the UN could not be directly imported.

The concept of social development was first mentioned in "The resolution on the improvement of the quality of population" adopted by the Advisory Council on Population Problems (that is a council of the Ministry of Health and Welfare) in July $1962 .{ }^{2}$ In the resolution, the concept of social development was used to refer to improvements to the health and welfare of the population in the context of measures to develop

\footnotetext{
${ }^{2}$ At that time, the most important organisation to shape policy direction on population issues was the council, which was established in 1953 (abolished in 2000). Tachi, as the president of the National Institute of Population Problems, played a central role in the management of the council. For details about the council see Atoh (2000).
} 
and improve human abilities. The resolution suggested eight policy issues for improving the quality of the population. One of the eight issues was "to extend the social security system, including the establishment of a child allowance scheme". This was explained as follows: "the social security system should be extended appropriately and powerfully, for it eliminates the waste of human abilities, and is extremely effective in maintaining and improving the workforce, and also guarantees a life without fear". In this resolution, the social security system was seen within the context of the development of human resources.

The resolution further states that "Japan now has placed too much importance on economic development", "The idea of social development should be taken seriously", "We should attach more importance to the development of individual ability", "We should make an effort to increase the proportion of well-educated population", "We place a particular emphasis on the healthy growth of the nation's children". On the surface, these ideas echo those from the original eugenic-euthenic thought. However, the resolution placed much importance on the euthenic approach through social policy to achieve the development of the quality of the population by improving the environment, for example, the resources available to the population to achieve greater skills, vitality and health. This was the effect of importing the concept of social development. The emphasis on human resource development was a novelty in the renewed eugenic-euthenic debate and shifted towards a more inclusive family policy agenda as opposed to one of selection.

This change was widely shared by senior members of the Ministry of Health and Welfare at that time. Tachi and his colleagues introduced the concept of social development into the Japanese social administration. The 1962 White Paper on Health and Welfare (Ministry of Health and Welfare 1963) devoted an entire chapter to the development of individual ability. The paper pointed out a growing worldwide interest in developing human ability. The issues raised in the paper enhanced interest in increasing the number of superior human beings in terms of physical strength, intellect and vitality through social policy, with less emphasis on eugenic ideas. The establishment of the Social Development Research Institute (Shakai Hosho Kenkyusho) in 1965 was a symbolic event in taking the first step to initiate discussions for providing high-quality social services in Japan. 
Table 16.1 Policy priorities of social administration in post-war Japan (1950-1990s)

\begin{tabular}{|c|c|c|c|c|}
\hline Period & $\begin{array}{l}\text { Fertility } \\
\text { rate }\end{array}$ & Aging ratio & Policy issue & Dominant theory \\
\hline 1950s & $\begin{array}{c}3.65 \text { (in } \\
1950)\end{array}$ & $\begin{array}{l}4.9 \text { (in } \\
1950)\end{array}$ & Population control & Family planning \\
\hline $1960 s$ & $\begin{array}{c}2.00 \text { (in } \\
1960)\end{array}$ & $\begin{array}{r}5.7 \text { (in } \\
1960)\end{array}$ & $\begin{array}{l}\text { Non-economic } \\
\text { development } \\
\text { Urbanisation }\end{array}$ & $\begin{array}{l}\text { Social development } \\
\text { Regional } \\
\text { development }\end{array}$ \\
\hline 1970s & $\begin{array}{c}2.13 \text { (in } \\
1970)\end{array}$ & $\begin{array}{c}7.1 \text { (in } \\
1970)\end{array}$ & Population aging & Welfare \\
\hline $1980 s$ & $\begin{array}{c}1.75 \text { (in } \\
1980 \text { ) }\end{array}$ & $\begin{array}{l}9.1 \text { (in } \\
1980 \text { ) }\end{array}$ & & \\
\hline 1990s & $\begin{array}{c}1.54 \text { (in } \\
1990 \text { ) }\end{array}$ & $\begin{array}{c}12.0 \text { (in } \\
1990 \text { ) }\end{array}$ & Low fertility & Family support \\
\hline
\end{tabular}

Furthermore, "social development" as a catchphrase was adopted by Prime Minister Eisaku Sato in 1964. The next Prime Minister, Kakuei Tanaka, who was elected in 1972, had become increasingly aware of the importance of social policy. Social development seems to have been established as a common value in the period of rapid industrial growth in the 1960s and became the precondition for the era of welfare in the 1970s.

\section{$4 \quad$ Population Trends and Family Policy Debates}

The concept of social development as adapted to Japan appeared in the policy debates on human resources and social security including the child allowance issue. Table 16.1 illustrates the changes in the policy priorities of social administrations in the post-war era. The theory of family planning in the 1950s and the theory of social development in the 1960s were formed through the policy debates on population. In 1970, the proportion of the Japanese population aged sixty-five and over was 7.1 percent, which means that Japan became an aging society. Following this, an ageing population became a major policy issue in the 1970s.

Entering the 1960s, interest in the policy debates on population issues rapidly shifted from quantitative control of the population to the qualitative improvement of the population following the UN's concepts and the 
euthenic strand of eugenic-euthenic ideas in Japan. In this trend, population issues began to intersect with child welfare issues as part of the concept of social development. In March 1962, Hirokichi Nadao, the Minister of Health and Welfare, consulted with the Central Child Welfare Council to request advice for the sound development of youth. The consultation mentioned the growing concern about the forthcoming shrinkage of the young population (in particular future labour shortages) and the increasing number of delinquent children. Four months later, the report by the Council proposed to reform the child welfare system to play a greater role in improving the quality of the population and to do so with an improved family policy.

In such a situation, the start of full-scale discussions on a child allowance marked a turning point in Japanese family policy. Tachi (1965), who brought the UN's concept of social development to Japan, was one of the eight members of the special committee on child allowance established in the Central Child Welfare Council. He believed the child allowance scheme was necessary because, for him, a reduction in human resources would be expected due to a decrease in the fertility rate in the future. The committee insisted that family policy should be for all children, not just for children in needy families. Since the 1960s, the idea of "promoting the sound development of children" has been widespread in family policy debate. Tachi, who was the only specialist on population problems in the committee, was, at that time, one of the few experts who emphasised the issue of the rapid fertility decline. He insisted that the introduction of the child allowance scheme was necessary for improving human resources across the population spectrum. He thought it was important to improve the quality of population in making up for the decline in quantity, but wanted to provide additional incentives to encourage quantity as well.

For him, the child allowance scheme was a population policy aimed at increasing a healthy young population. ${ }^{3}$ During the discussions for introducing a child allowance scheme in the 1960s, a consensus among committee members emerged on the social responsibility for raising children. This was a new epoch in the history of family policy thought in Japan and

\footnotetext{
${ }^{3}$ However, the discussion of the downward trend in the fertility rate was not the mainstream social policy debate at the time. It was only in the 1990s when a sense of crisis in the declining number of children came to be widely shared in Japan.
} 
marked a departure from the idea centred on population control, to the idea centred on the quality of life of all individuals.

\section{Conclusion}

As I have discussed, the concept of social development that appeared in the context of development assistance in the UN brought a dramatic change to debates on population issues in Japan.

To conclude, I would like to raise three insights about the international diffusion of policy ideas. First, policy ideas are not introduced straightforwardly. Ideas born in advanced countries or international organisations are not simply "diffused". The points stressed may be different, even when the literal definition is the same. As discussed in this chapter, the idea of social development originated in the UN, but it changed in the Japanese context. In Japan, the focus shifted to the development of human resources, which was not emphasised in the UN version. Thus, the social development basis for extending family policy included both UN and non-UN originated ideas such that it is appropriate to speak of adaptation rather than simple diffusion here.

Second, it is important to pay attention to the historical contexts in the receiving country when studying the diffusion of policy ideas. Domestic contexts always transform the meaning of policy ideas. On the other hand, accepting a policy idea also changes the domestic context. It is necessary to analyse the interaction between the two. In this paper, the context of eugenic-euthenic thought from the pre-war era was fundamental, but it is also important that, as a result of accepting the idea of social development, the point being stressed moved from its eugenic aspect to its euthenic aspect.

Third, the import of a policy idea is not an automatic process. Attention should be paid to the active role of policy intellectuals in introducing policy ideas. On the basis of the domestic context and their role there, policy intellectuals carefully select policy ideas from abroad, and sometimes introduce them with different meanings and emphasis. In this paper, Tachi's previous career was the decisive factor. Before introducing the idea of social development into Japan, he was an expert in population studies, having been a leader of the eugeniceuthenic thought since the prewar era. 


\section{References}

Atoh, Makoto. 2000. Jinkomondaishingikai Saishusokai ni Yosete (An Essay

Written for the Last Round of General Meeting of the Advisory Council on Population Problems). Jinko Mondai Kenkyu (Journal of Population Problems) 56 (4): 88-93.

Kita, Akemi. 2008. 1960nendai niokeru Jidoteateron no Ittan: 'Ahakaiteate' wo Meguru Tairitsu (Discussions on Child Benefits in the 1960's: The Weak Development of Demogrants in Japan). Shakai Seisaku Gakkaishi 19: 161-175. Ministry of Health and Welfare. 1963. Kosei Hakusho (The Fiscal 1962 White Paper on Health and Welfare). Tokyo: Finance Ministry's Printing Bureau.

Ohshio, Mayumi. 1996. Jido Teate no Kenkyu (A Study on Child Allowance System). Kyoto: Horitsubunkasha.

Ono, Taichi. 2014. Shakaihosho, Sono Seisakukatei to Rinen (Historical Studies on Ideals and Principles of Social Security in Japan). Tokyo: Shakaihoken Kenkyusho. Sugita, Naho. 2017. Jinkoron Nyumon (Introduction to Population Studies). Kyoto: Horitsubunkasha.

Tachi, Minoru. 1965. Shakai Kaihatsu nitsuiteno Kaisetsu (An Explanation on Social Development). Tokyo: Koseisho Jinkomondai Kenkyusho (National Institute of Population Problems).

United States President. 1964. U.S. Participation in the UN. Washington:

U.S. Government Printing Office.

United States Welfare Administration. 1966. Social Development: Key to the Great Society. Washington: U.S. Government Printing Office.

Open Access This chapter is licensed under the terms of the Creative Commons Attribution 4.0 International License (http://creativecommons.org/licenses/ by/4.0/), which permits use, sharing, adaptation, distribution and reproduction in any medium or format, as long as you give appropriate credit to the original author(s) and the source, provide a link to the Creative Commons licence and indicate if changes were made.

The images or other third party material in this chapter are included in the chapter's Creative Commons licence, unless indicated otherwise in a credit line to the material. If material is not included in the chapter's Creative Commons licence and your intended use is not permitted by statutory regulation or exceeds the permitted use, you will need to obtain permission directly from the copyright holder. 